\title{
Architektura informacji jako problem badawczy informatologii
}

\author{
Piotr Tafiłowski \\ Katedra Informatologii, Wydziat Dziennikarstwa, Informacji i Bibliologii \\ Uniwersytet Warszawski
}

\begin{abstract}
Abstrakt
Cel/Teza: Celem artykułu jest zaprezentowanie refleksji nad związkami pomiędzy architekturą informacji a informatologią, zarówno w zakresie badań naukowych, jak i dydaktyki uniwersyteckiej. Koncepcja/Metody badań: Rozważania dotyczące miejsca architektury informacji w systemie nauki o informacji podjąłem jako pracownik jednego z instytutów prowadzących badania w zakresie bibliologii i informatologii, który planował uruchomić kierunek studiów pod nazwą „Architektura informacji". Było to konieczne, ponieważ plany utworzenia takiego kierunku spotkały się z niezrozumieniem powiązań tego obszaru badań i działalności praktycznej z bibliologią i informatologią ze strony rady wydziału.

Wyniki i wnioski: Refleksja nad zakresem zagadnień wchodzących w pole zainteresowań architektury informacji z jednej strony, z drugiej zaś nad problematyką badawczą informatologii oraz nad programami studiów prowadzonych w jej zakresie wskazuje, że architektura informacji w wysokim stopniu wpisuje się w zakres zainteresowań informatologów.

Oryginalność/Wartość poznawcza: Podjęcie tego typu rozważań oraz podanie uargumentowanej odpowiedzi na pytanie „Dlaczego informatolodzy powinni uczyć architektury informacji?” wydają się być uzasadnione przy wzięciu pod uwagę, iż wnioski o utworzenie takiego kierunku studiów w ramach naszej dyscypliny budziły kontrowersje i zastrzeżenia kolegów z innych instytutów czy też władz uczelni, zaś kompetencje informatologów w tym zakresie bywają kwestionowane. Prezentowany tekst pozwala na rozwianie wątpliwości w tym zakresie. Refleksji takiej do tej pory nikt jeszcze nie przedstawił.
\end{abstract}

\section{Słowa kluczowe}

Architektura informacji. Kształcenie. Nauka o informacji. Informatologia.

Otrzymany: 23 września 2016. Z Zrecenzowany: 15 listopada 2016. Zaakceptowany: 14 grudnia 2016.

\section{Wstęp}

W Polsce bibliotekoznawstwo i informacja naukowa tradycyjnie wywodzą się z badań nad bibliografią, z historii literatury oraz z nauk pomocniczych historii. Obecnie dyscyplina ta, pod nazwą bibliologia i informatologia, odchodzi od swych korzeni tkwiących w historii, a także od zagadnień księgoznawczych i zwraca się ku badaniom nad społeczeństwem informacyjnym i nowymi technologiami informacyjnymi ${ }^{1}$. Już od lat 50 . XX w. w bibliotekoznawstwie i bibliografii daje się odnotować wzrost zainteresowania zastosowaniami technologii

\footnotetext{
${ }^{1}$ Na temat genezy i historii nauki o informacji zob. Cisek, 2002, 47-52.
} 
komputerowych, czego efektem były przekształcenia obu tych obszarów. Przyczyniło się to do ukształtowania współczesnej nauki o informacji (informatologii) (Sosińska-Kalata, 2004). Dalszym skutkiem tych zmian było coraz głębsze zainteresowanie problematyką funkcjonowania informacji w społeczeństwie, z czego wyrosły m.in. zarządzanie informacją i architektura informacji. Na przełomie pierwszej i drugiej dekady XXI w. nastąpił gwałtowny zwrot kierunków badań, w znacznej mierze wymuszony przez zainteresowania młodych ludzi, kandydatów na studia. Badania nad dawną książką (bibliologia historyczna) stają się w coraz większym stopniu domeną historyków² ${ }^{2}$ Instytuty i katedry zajmujące się kształceniem i badaniami w zakresie bibliologii i informatologii, by przyciągnąć kandydatów, uruchamiają nowe kierunki studiów i zachęcają młodych ludzi specjalizacjami czy ścieżkami studiów takimi jak na przykład: Zarządzanie informacją i wiedzą (Uniwersytet Warszawski), Publikowanie cyfrowe i sieciowe (Uniwersytet Wrocławski), Zarządzanie informacją i bibliologia (Uniwersytet Mikołaja Kopernika w Toruniu) czy Zarządzanie informacją i publikowanie cyfrowe (Uniwersytet Pedagogiczny w Krakowie) ${ }^{3}$. Jednym z elementów nowej oferty dydaktycznej są studia na kierunku Architektura informacji, uruchomione na UP w Krakowie, UMK oraz UMCS w Lublinie. W tym zakresie na Uniwersytecie Warszawskim od kilku lat prowadzona jest też specjalizacja na studiach magisterskich pod nazwą Architektura informacji i wiedzy.

Przedmiotem mojej refleksji w prezentowanym tekście nie jest to, czym jest architektura informacji, ponieważ to w podstawowym zakresie już dość dobrze wiemy (choć nasza wiedza o tej dziedzinie wciąż się pogłębia), lecz to, dlaczego problematyka ta może, a nawet powinna być przedmiotem badań oraz dydaktyki prowadzonych przez informatologów oraz jakie istnieją związki pomiędzy architekturą informacji a informatologią. Podjęcie takich rozważań oraz podanie uargumentowanej odpowiedzi na pytanie „Dlaczego informatolodzy powinni uczyć architektury informacji?” wydają się być uzasadnione, biorąc pod uwagę, iż wnioski o utworzenie takiego kierunku studiów w ramach naszej dyscypliny budziły kontrowersje i zastrzeżenia kolegów z innych instytutów czy też władz uczelni, zaś kompetencje informatologów w tym zakresie bywają kwestionowane.

W dalszej części tekstu będzie mowa o tym, że architektura informacji wciąż jeszcze jest obszarem badawczym in statu nascendi, który nie został dotychczas ostatecznie ukształtowany i ściśle zdefiniowany. Całkowity zakres jej zainteresowań, stosunek do innych dyscyplin naukowych oraz pełna definicja nadal stanowią przedmiot interdyscyplinarnej dyskusji, niemniej jednak uczestniczący w niej uczeni zgodni są co do zasadniczych kwestii: czym jest architektura informacji, jakimi problemami się zajmuje, na jakie pytania powinna odpowiadać, z jakimi wyzwaniami pozwala się mierzyć, co jest jej przedmiotem oraz jakie obszary (faktycznie lub potencjalnie) zagospodarowuje. Z tych względów nie proponuję własnej definicji architektury informacji. Biorąc jednak pod uwagę dotychczasowy stan badań uznaję za uprawnione stawianie pytań o jej funkcje, role, usytuowanie w systemie nauki czy dydaktykę.

Celem artykułu jest uporządkowanie bieżącej dyskusji nad architekturą informacji w kontekście nauki o informacji oraz sformułowanie i usystematyzowanie argumentów na rzecz

\footnotetext{
2 Zjawisko to można było zaobserwować w czasie konferencji jubileuszowej Profesora Edwarda Potkowskiego, zorganizowanej na UMCS w Lublinie przez Studenckie Koło Informacji Naukowej „Palimpsest”. Por. Tafiłowski, 2015.

${ }^{3}$ Zgodnie z informacjami prezentowanymi na stronach internetowych Instytutów, stan na 19 lipca 2016.
} 
związków obu obszarów badawczych na podstawie bieżącego stanu badań w tym zakresie. Trzeba mieć wszakże świadomość, że debata ta nie została jeszcze zakończona, a w jej toku pojawiać się będą nowe ustalenia, których obecnie nie sposób antycypować, lecz w miarę upływu czasu będą one wzbogacać stan naszej wiedzy oraz aktualizować rozumienie problematyki.

\section{Historia architektury informacji}

Od czasów prehistorycznych ludzkość produkuje i przetwarza informacje, utrwalając je za pomocą różnych technologii, takich jak zapisy na glinianych tabliczkach czy papirusach, w kodeksach pergaminowych, a następnie papierowych itd. Kilkakrotnie w toku dziejów dochodziło do rewolucji w technologiach informacyjnych, poczynając od wynalazku pisma, poprzez wynalezienie druku, aż do rewolucji informatycznej na przełomie XX i XXI wieku. Jednymi ze skutków owych przełomów były każdorazowe skokowe przyrosty ilości wprowadzanej do obiegu społecznego informacji (por. np. Briggs \& Burke, 2010; Eisenstein, 2004). Co z tego wynika, informacje należało także coraz skrupulatniej kategoryzować i strukturyzować, nadawać im taką formę, aby można je było sprawnie przekazywać i odtwarzać, wykorzystywać i stosować. Działania prowadzące do tego celu są niczym innym jak architekturą informacji.

Jako przykład najwcześniejszych zabiegów noszących takie właśnie cechy, pochodzących jeszcze z epoki kultury oralnej, można wymienić nadawanie eposom homeryckim specjalnej kompozycji, ułatwiającej ich zapamiętanie i deklamowanie (Gleick, 2012, 39-40). Jednak wraz z upływem czasu, wraz z wprowadzaniem do powszechnego użytku kolejnych technologii i narastaniem ilości dostępnej informacji, zagadnienie to ulegało coraz większej komplikacji. Obecnie mamy do czynienia ze zjawiskami informacyjnymi o skali niewyobrażalnej dla naszych przodków. Rzędy wielkości danych, do których mamy przynajmniej potencjalnie - dostęp, trudne są do oszacowania. Zjawisku temu opisujący je uczeni i dziennikarze nadają różne nazwy - bomby megabitowej, przeciążenia czy przeładowania informacyjnego itd. (Lem, 1974, 126-130; Blair, 2010; Koltay, 2012). Co więcej, znaczna część informacji wpuszczanych w kanały cyfrowe stanowi smog informacyjny. Dlatego też coraz ważniejszym wyzwaniem, w obliczu którego stają informatolodzy, infobrokerzy, pracownicy informacji, ale także zwykli jej użytkownicy, jest nie tyle sztuka wyszukiwania informacji, co jej selekcja, zarządzanie nią, odsiewanie tego, co nieistotne i nierelewantne, ocena jakości informacji. Potrzebujemy do tego nowych narzędzi oraz „standardów integrujących dziedziny wiedzy związanych z jej projektowaniem, udostępnianiem i zarządzaniem" (Skórka, 2002).

Jednym z możliwych rozwiązań wymienionych problemów może być zastosowanie technik architektury informacji. Służyć ona może zarówno pokonywaniu barier informacyjnych (Świgoń, 2006), jak i filtrowaniu oraz hierarchizowaniu informacji, dzięki czemu przyczyniać się może do usprawniania procesów komunikacji społecznej, zwłaszcza w środowisku cyfrowym, w tym także komunikacji naukowej ${ }^{4}$. Architektura informacji zatem

\footnotetext{
${ }^{4}$ Warto w tym miejscu zaznaczyć, że techniki, które obecnie zaliczyć można do dziedziny architektury informacji, od wielu stuleci stosowane są w klasyfikacji nauk. Por. Burke, 2016. Obecnie odgrywa ona coraz większą rolę w systematyzacji narastającej w szybkim tempie wiedzy.
} 
stanowi jeśli nie rozwiązanie, to przynajmniej odpowiedź na część problemów, które bada nauka o informacji. Tak w sposób bardzo skrótowy przedstawić można historyczną genezę i obecne zadania architektury informacji ${ }^{5}$.

\section{Architektura informacji a informatologia}

Jednym z możliwych podejść do wypracowywania takich standardów, które mają pomagać użytkownikom w radzeniu sobie z szumem informacyjnym, jest rozwijanie kompetencji informacyjnych (ang. Information Literacy), które stały się przedmiotem nowego interdyscyplinarnego kierunku badań. Zarówno studia teoretyczne, jak i działania praktyczne w tym zakresie prowadzą specjaliści z zakresu informacji naukowej oraz bibliotekoznawcy i bibliotekarze (Federowicz \& Ratajewski, 2015; Kurkowska, 2012; Hoechsmann \& Poyntz, 2012; Lau, 2011; Piotrowska, 2011; Derfert-Wolf, 2009; Próchnicka, 2007; Derfert-Wolf, 2005). Jest to kolejna wskazówka pozwalająca połączyć architekturę informacji z informatologią.

Informatologia jest dyscypliną naukową badającą całokształt zagadnień teoretycznych i praktycznych związanych z wytwarzaniem, wyszukiwaniem, przetwarzaniem, przesyłaniem, odbieraniem i wykorzystywaniem informacji. W zakres jej zainteresowań wchodzą zatem problemy zasobów informacyjnych, dystrybucji i konsumpcji informacji, procesy i zachowania komunikacyjne i informacyjne, a wreszcie kwestie technologiczne związane z projektowaniem systemów informacyjnych oraz korzystaniem z nich.

Profesor Maria Dembowska wyróżniła pięć pól badawczych (ukierunkowań) dla tej dyscypliny, a wśród nich m.in. orientację cybernetyczną, prakseologiczną oraz systemową. Pierwsza z nich dotyczy wszystkich procesów informacyjnych związanych z pozyskiwaniem i przekazywaniem danych, druga ma na celu optymalizację i usprawnienie działalności informacyjnej, zgodnie z trzecią zaś, podstawą nauki o informacji jest teoria systemów (Dembowska, 1999, 166-167).

Architekturę informacji definiuje się jako po części naukę, po części zaś sztukę kształtującą praktyczne umiejętności organizowania, systematyzowania, strukturyzowania, hierarchizowania informacji w taki sposób, by zapewnić jej jak największą użyteczność, ułatwić użytkownikom jej wyszukiwanie, zrozumienie, kontekstualizację, administratorom zaś ułatwić zarządzanie nią (Farnum, 2002, 34). Najpopularniejsze definicje architektury informacji podał Stanisław Skórka:

(1) Proces organizowania, nazewnictwa, projektowania nawigacji i systemów wyszukiwawczych pomocnych w znajdowaniu i zarządzaniu informacją.

(2) Projektowanie strukturalne udostępnianych w sieci środowisk informacyjnych.

(3) Sztuka oraz nauka organizowania informacji w celu ułatwienia ludziom efektywnego zaspokojenia ich potrzeb informacyjnych.

(4) Sztuka, nauka i działalność polegająca na organizowaniu informacji w taki sposób, aby miała ona sens dla jej odbiorców (Skórka, 2002).

Gdy rozważa się architekturę informacji z punktu widzenia nauki o informacji, odróżnić należy architekturę informacji jako projekt graficzny (ang. visual design) (projektowanie interfejsów, np. stron WWW) od projektowania systemu informacyjnego zorientowanego

\footnotetext{
${ }^{5}$ Szerzej na temat historii architektury informacji w XX wieku zob. Resmini \& Rosati, 2012.
} 
na użytkownika i jego potrzeby. Celem tego drugiego procesu jest jak najefektywniejsze zaspokojenie tychże potrzeb. Odrębną kwestią będzie ewaluacja systemu, która powinna zapewnić jego wysoką wydajność i przyjazność dla użytkowników końcowych oraz administratorów. Interesuje nas zatem architektura informacji jako proces zarządzania informacją i nadawania logicznych struktur systemowi informacyjnemu.

Głębsza refleksja nad architekturą informacji jako interdyscyplinarnym obszarem studiów rozpoczęła się od badań i pomiarów funkcjonalności w serwisach internetowych, jednak jak wyjaśniłem powyżej, zagadnienie to jest o wiele dawniejsze, szersze i dotyczy informacji nie tylko we wszelkiego rodzaju systemach cyfrowych, lecz także we wszystkich tradycyjnych systemach informacyjnych (o tym niżej). Pole zainteresowań architektury informacji jest interdyscyplinarne, osoby zajmujące się nią powinny posiadać różnorodne umiejętności i kompetencje techniczne z zakresu projektowania grafiki, tworzenia instrukcji, interakcji pomiędzy komputerem a człowiekiem, nauk komputerowych, a także dyscyplin humanistycznych, metodologii etnografii (przy czym problematyka badawcza, ze względu na prowadzone w jej zakresie badania użytkowników, bliższa jest raczej antropologii kulturowej) oraz nauk o informacji. Jako taka, architektura informacji z pewnością nie może być zatem wyłącznym przedmiotem badań informatyków (podobnie jak system informacyjny nie jest tym samym co system informatyczny, architektura informacji nie jest tym samym, co architektura systemów informacyjnych, choć czasem te dwa pojęcia bywają używane zamiennie), a co więcej - w ogóle nie da się jej zamknąć w ramach jednej dyscypliny. Badania nad nią rozwijają ekonomiści, komunikolodzy, archiwiści oraz bibliolodzy i informatolodzy. Można natomiast pokusić się o wskazanie, której z dyscyplin w realiach nauki polskiej jest do niej najbliżej, która obejmuje swoim zakresem najwięcej zagadnień związanych z architekturą informacji.

W ciągu ostatnich mniej więcej dwudziestu pięciu lat nastąpiła prawdziwa eksplozja zainteresowania architekturą informacji. Jest to dziedzina, której znaczenie, mimo jej dotychczasowej amorficzności, wciąż wzrasta (Martin et al., 2010). Wyszukiwanie frazy information architecture za pomocą multiwyszukiwarki w bazach danych udostępnianych przez Bibliotekę Główną UMCS w Lublinie dało 272 604 unikalne wyniki (stan na 13 czerwca 2016). Znajdują się tu opublikowane w wielu językach książki, artykuły w czasopismach naukowych i prasie, recenzje, materiały konferencyjne, raporty techniczne i inne. Wiele z nich dotyczy zastosowania architektury informacji w bibliotekach, szczególnie w odniesieniu do projektowania bibliotecznych witryn internetowych oraz ich kolekcji cyfrowych. Dla porównania wyszukiwanie tej samej frazy w bazie SCOPUS dało ogółem 120421 dokumentów, w dziale „Computer Science” - 70 830, zaś w „Social Sciences” - 4106. W tej bazie publikacje z zakresu bibliotekoznawstwa czy informatologii stanowią jedynie wąski margines dostępnego zasobu dokumentów. Najbardziej precyzyjne wyszukiwanie oferuje baza LISTA (Library, Information Science \& Technology Abstracts na platformie EBSCOhost). Dostępnych jest w niej 635 tekstów poświęconych architekturze informacji ${ }^{6}$.

Niestety, pomimo znacznej popularności tego zagadnienia oraz uruchamiania związanych z nią kierunków studiów i specjalności (nie tylko zresztą w ośrodkach informatologicznych, np. taką specjalność oferuje Akademia Humanistyczno-Ekonomiczna w Łodzi, na której stronie internetowej nota bene możemy przeczytać piękne sformułowanie: „Misją

\footnotetext{
${ }^{6}$ Kwerendy w bazach SCOPUS i LISTA wykonane zostały 19 lipca 2016.
} 
architektury informacji jest humanizowanie technologii”), polska literatura przedmiotu prezentuje się dotychczas nader skromnie. Zauważyć trzeba, że termin ten nie pojawia się w podręczniku przeznaczonym dla studentów kształcących się w zakresie zarządzania informacją (aczkolwiek został on napisany z myślą o kierunku archiwistyka i zarządzanie dokumentacją, nie zaś dla informatologów) (Roman, 2012). Niemniej jednak, różnymi aspektami architektury informacji zajmuje się coraz więcej polskich informatologów, wykorzystując jej zasady w analizach i ocenie usług online, takich jak biblioteki cyfrowe, serwisy internetowe czy usługi mobilne. Mówi się o niej także w kontekście organizacji wiedzy czy zarządzania informacją ${ }^{7}$.

Jak wynika z przytoczonych powyżej definicji architektury informacji, obejmuje ona także powstające od ponad stulecia klasyfikacje biblioteczne, takie jak na przykład Uniwersalna Klasyfikacja Dziesiętna (Sosińska-Kalata, 1995) czy słowniki haseł przedmiotowych. Spójrzmy na jedną z definicji:

Język Haseł Przedmiotowych Biblioteki Narodowej (...) będący narzędziem opisu zawartości dokumentów gromadzonych w bibliotekach, pozwala tworzyć adekwatne, poprawne terminologicznie i językowo, spójne punkty dostępu do treści - służy zapisywaniu informacji przez bibliotekarzy i jej wyszukiwaniu przez użytkowników systemu informacyjnego (Kędzielska et al., 2013, 1).

Innymi słowy, JHP służy budowaniu pewnej struktury informacji, która ułatwiać ma korzystanie z niej. Jest to zatem proces należący do dziedziny architektury informacji.

Uprawnienia bibliotekoznawstwa i bibliologii do badań nad klasyfikacjami bibliotecznymi nie są kwestionowane, analogicznie więc wydaje się zasadne niekwestionowanie praw informatologii do badań nad architekturą informacji. Zagadnienie, czy też problem, oraz przedmiot badań pozostaje bowiem ten sam, zmienia się jedynie technologia. Co za tym idzie, mamy w tym przypadku do czynienia głównie ze zmianą ilościową, a nie jakościową.

Zgodnie z ujęciem cybernetycznym według definicji M. Dembowskiej, procesy informacyjne, takie jak pozyskiwanie, wyszukiwanie i przekazywanie informacji podlegają strukturyzacji. Bez zastosowania architektury informacji w systemach, które mają służyć temu celowi, wyszukiwanie informacji byłoby znacznie utrudnione, o ile w ogóle niemożliwe. Architektura informacji pozwala na takie organizowanie informacji (danych), aby użytkownik mógł je odszukać w jak najprostszy sposób (budowanie baz danych, a także systemów metadanych, czy systemów organizacji wiedzy, takich jak różnego rodzaju taksonomie, kartoteki wzorcowe, tezaurusy itp.). Chodzi tu jednak nie tylko o wewnętrzną strukturę bazy danych, ale także np. o projektowanie interfejsów użytkownika w taki sposób, by były one jak najprostsze w obsłudze i intuicyjne. Wiąże się to także bezpośrednio z ujęciem drugim, prakseologicznym - usprawnianie i optymalizacja działalności informacyjnej w systemach cyfrowych nie są możliwe bez zastosowania metod i narzędzi architektury informacji; ściśle rzecz biorąc, stosowanie reguł architektury informacji jest na to jedynym sposobem. Usprawnianie tradycyjnych procesów informacyjnych (takich jak obsługa użytkownika przez pracownika informacji, biblioteczne systemy magazynowania itd.) bez optymalizacji systemów, obecnie głównie już cyfrowych, nie mogłoby przynieść oczekiwanych rezultatów.

7 W nowym podręczniku zatytułowanym Nauka o informacji, przygotowanym pod red. W. Babika, znajduje się rozdział Architektura informacji autorstwa Stanisława Skórki. Podręcznik został wydany przez SBP w 2016 r., po złożeniu artykułu i zaakceptowaniu go do druku [red.]. 
Kluczowe znaczenie ma tu bowiem metainformacja. Najbogatszy nawet księgozbiór ma dla czytelnika tylko taką wartość, jaką prezentuje katalog umożliwiający dostęp do zawartych w nim dzieł, czyli jaka jest informacja o nim. Jeśli użytkownik nie będzie w stanie odnaleźć informacji o jakimś obiekcie, która pozwoli mu dotrzeć do niego, sam ten obiekt stanie się bezużyteczny.

Konieczność odpowiedniej strukturyzacji i hierarchizacji informacji i wiedzy narzuca również teoria systemów. Teoria ta, pierwotnie wywodząca się z biologii, rozwinięta została przez cybernetyków, a obecnie korzystają z niej także nauki społeczne i ekonomiczne, informatyka i kognitywistyka. Jej celem jest holistyczne objaśnienie funkcjonowania organizmów żywych, społeczeństw, a wreszcie systemów cybernetycznych i informatycznych. Jednym z praktycznych zastosowań teorii systemów jest metateoria uporządkowania wiedzy, funkcjonująca pod akronimem TOGA, czyli

globalna systemiczna obliczeniowa struktura teorii dla wszystkiego (ale nie wszystkiego) (...) TOGA jest narzędziem zorientowanego na cel porządkowania wiedzy (modelowania konceptualnego) dla specyfikacji i identyfikacji systemów/procesów istniejących w złożonym świecie rzeczywistym (Gadomski, 1997).

Architektura informacji jest niezbędnym elementem procesów wszechogarniającej digitalizacji. Digitalizacja, umieszczanie obiektów w systemach cyfrowych, publikowanie w Internecie to procesy, którymi objęte są także jednostki stanowiące tradycyjne pole badań bibliologii (rękopisy, starodruki, książki nowe, czasopisma itd., a także katalogi). Trend ten jest nieodwracalny. Nie jest jednak możliwe zbudowanie dobrej biblioteki cyfrowej bez zastosowania rozwiązań wypracowanych na gruncie architektury informacji, bez zbudowania struktury, w której umieszczone zostaną udostępniane obiekty i ich opisy (por. np.: Carr, 2015; Chen \& Lin, 2014; Morville \& Sullenger, 2010; Carnegie \& Abell, 2009; Hider et al., 2009). Nie jest to także możliwe bez interdyscyplinarnej współpracy informatyków i humanistów (bibliotekarzy, bibliologów, historyków), a do tego potrzebna jest nam jakaś dyscyplina integrująca. Rolę tę, w moim przekonaniu, w najdoskonalszy sposób odgrywać może informatologia. Co więcej, w przyszłości systemy cyfrowe budowane z „zawartości informacyjnej” bibliotek tradycyjnych, będą z pewnością o wiele bardziej skomplikowane niż proste biblioteki cyfrowe, jakie znamy dziś. Będą to być może mapy wiedzy czy sieci semantyczne, a w ich tworzeniu znajomość reguł architektury informacji, realizowanych w ścisłej współpracy przez przedstawicieli różnych dyscyplin, będzie umiejętnością jeszcze bardziej kluczową (Lozowick, 2009).

Także w refleksji teoretycznej architektura informacji została już kilkanaście lat temu włączona w zakres zainteresowań bibliologii i informatologii, przede wszystkim w USA (Robins, 2002). W Polsce najbardziej znanym informatologiem zajmującym się tą problematyką jest Stanisław Skórka z Uniwersytetu Pedagogicznego w Krakowie. Wśród przedstawicieli dyscypliny istnienie takiego związku nie budzi żadnych wątpliwości. Informatologia jako dyscyplina obejmująca całokształt zagadnień teoretycznych i praktycznych związanych z działalnością informacyjną de facto włączyła już architekturę informacji w zakres własnych badań. Odwracając problem, jest równie oczywiste, że architektura informacji stanowi integralną i ważną część zagadnień zarówno teoretycznych, jak i praktycznych związanych z działalnością informacyjną, nawet jeśli potraktujemy ją tylko w wąskim, potocznym ujęciu, odnoszącym to pojęcie jedynie do stron internetowych. Podstawową 
funkcją niemal wszystkich stron internetowych jest funkcja informacyjna, a zatem stanowią one przedmiot badań informatologii jako narzędzie (medium) procesów informacyjnych. A dyscyplina ta bada nie tylko same procesy oraz ich narzędzia (media), ale także sposoby tworzenia tychże narzędzi, analogicznie jak przedmiotem zainteresowań bibliologii jest całokształt studiów nad książką nie tylko jako tekstem, ale także jego fizycznym nośnikiem (produkcją i konsumpcją).

Warto podkreślić, że autorzy opracowań poświęconych architekturze informacji w jej aspekcie technologicznym odwołują się do metafor i porównań z zakresu bibliologii, takich jak książka czy biblioteka (Rosenfeld \& Morville, 2002, 23-24; Henrique \& Câmara, 2014). Zwracają oni uwagę, że biblioteki są również systemami informacyjnymi, które zostały zaprojektowane w precyzyjnie określony sposób, zatem do nich również odnosi się pojęcie architektury informacji. Analogie i wzajemne wpływy bibliologii i informatologii oraz architektury informacji są zatem obustronne i niewątpliwe.

\section{Zakończenie}

Z tego, co powiedziałem powyżej wynika, że informatologia włączyła w zakres swoich zainteresowań architekturę informacji jako zjawisko z zakresu nauk społecznych i element procesu komunikowania (komunikacji społecznej), bez jej aspektów ściśle technologicznych, którymi zajmuje się informatyka. Ma do tego prawo jako dyscyplina humanistyczna posługująca się m.in. metodologią nauk społecznych. Różnorodne zagadnienia związane z podstawami organizacji i działaniem systemów informacyjno-wyszukiwawczych znajdują się w polu zainteresowań badawczych tej dyscypliny już od drugiej połowy XX wieku (Dembowska, 1991). Co więcej, przegląd programów studiów na kierunkach informatologicznych oraz wykładanych w ich ramach przedmiotów ${ }^{8}$ wskazuje, że obejmują one w zasadzie wszystkie elementy, znane już z definicji architektury informacji. Innymi słowy, przyjąć można, że studia z zakresu nauki o informacji kształciły studentów w zakresie architektury informacji na długo zanim expressis verbis w ten sposób nazwano nowy kierunek kształcenia.

\section{Bibliografia}

Blair, A.M. (2010). Too Much to Know: Managing Scholarly Information before the Modern Age. New Haven; London: Yale University Press.

Briggs, A.; Burke, P. (2010). Spoteczna historia mediów: od Gutenberga do Internetu. Warszawa: Wydaw. Nauk. PWN.

Burke, P. (2016). Społeczna historia wiedzy. Warszawa: Wydaw. Aletheia.

Carnegie, T.A.M.; Abell, J. (2009). Information, Architecture, and Hybridity: The Changing Discourse of the Public Library, Technical Communication Quarterly, 18 (3), 242-258.

Carr, P.L. (2015). Serendipity in the Stacks: Libraries, Information Architecture, and the Problems of Accidental Discovery, College E Research Libraries 76 (6), 831-842.

Chen, C.-M.; Lin, S.-T. (2014). Assessing Effects of Information Architecture of Digital Libraries on Supporting E-learning: A Case Study on the Digital Library of Nature \& Culture, Computers E Education 75, 92-102.

\footnotetext{
${ }^{8}$ Nie podaję konkretnych przykładów, gdyż nazwy i zestawy przedmiotów zmieniają się dość dynamicznie.
} 
Cisek, S. (2002). Filozoficzne aspekty informacji naukowej. Kraków: Wydaw. UJ.

Dembowska, M. (1991). Nauka o informacji naukowej (informatologia). Organizacja i problematyka badań w Polsce, Warszawa: IINTE.

Dembowska, M. (1999). Bibliologia, bibliografia, bibliotekoznawstwo, informacja naukowa: wybór prac. Warszawa: PAN. Biblioteka.

Derfert-Wolf, L. (2005). Information literacy - koncepcje i nauczanie umiejętności informacyjnych [online], Biuletyn EBIB 1 (62), [11.09.2016],http://www.ebib.pl/2005/62/derfert.php

Derfert-Wolf, L. (2009). Information literacy - kształcenie umiejętności informacyjnych w bibliotekach akademickich. W: B. Antczak-Sabala, M. Kowalska, L. Tkaczyk (red.). Przestrzeń informacyjna biblioteki akademickiej - tradycja i nowoczesność. Toruń: Wydaw. WSB, 185-208.

Eisenstein, E.L. (2004). Rewolucja Gutenberga. Warszawa: Prószyński i S-ka.

Farnum, C. (2002). Information Architecture: Five Things Information Managers Need to Know, The Information Management Journal, 36 (5), 33-37.

Federowicz, M.; Ratajewski, S. (red.). (2015). O potrzebie edukacji medialnej w Polsce, Warszawa: KRRiT.

Gadomski, A.M. (1997). Global-TOGA Meta-Theory [online], Meta-Knowledge Engineering \& Management (MKEM) Research Server for High-Intelligent Socio-Cognitive Systems [23.09.2016], http://erg4146.casaccia.enea.it/wwwerg26701/Gad-toga.htm

Gleick, J. (2012). Informacja : bit-Wszechświat-rewolucja. Kraków: Wydaw. Znak.

Henrique, G.; Câmara, G.F. (2014). Arquitetura da informação em livros: uma aproximação a partir do comportamento de busca dos usuários [online], Biblios 55 [11.09.2016],http://biblios.pitt.edu/ ojs/index.php/biblios/article/view/152

Hider, Ph.; Burford, S.; Ferguson, S. (2009). The Use of Supporting Documentation for Information Architecture by Australian Libraries, Journal of Web Librarianship, 3 (1), 55-70.

Hoechsmann, M.; Poyntz, S.R. (red.). (2012). Media Literacies : A Critical Introduction, Malden-Oxford: Blackwell Publishing.

Kędzielska, J.; Klenczon, W.; Stolarczyk, A. (red.). (2013). Stownik Języka Haset Przedmiotowych Biblioteki Narodowej (stan na 31 sierpnia 2013 roku). Warszawa: BN.

Koltay, T. (2012). Information Architecture, Information Overload, and the Literacies [online]. Journal of Information Architecture, vol. 4, no. 1-2, [11.09.2016], http://journalofia.org/volume4/ issue2/04-koltay/

Kurkowska, E. J. (2012). Edukacja informacyjna w bibliotekach a rozwój spoteczeństwa wiedzy. Warszawa: Wydaw. SBP.

Lau, J. (2011). Kompetencje informacyjne w procesie uczenia się przez całe życie : wytyczne. [online] Warszawa: Wydaw. SBP, [11.09.2016],http://www.ifla.org/files/assets/information-literacy/publications/ifla-guidelines-pl.pdf

Lem, S. (1974). Summa technologiae. Kraków: Wydaw. Literackie.

Lozowick, Y. (2009). Mapy wiedzy i biblioteki. Przeglad Informacyjno-Dokumentacyjny 39 (3), 86-91.

Martin, A.; Dmitriev, D.; Akeroyd, J. (2010). A resurgence of interest in Information Architecture, International Journal of Information Management 30, 6-12.

Morville, P.; Sullenger, P. (2010) Ambient Findability: Libraries, Serials, and the Internet of Things, The Serials Librarian, 58 (1-4), 33-38.

Piotrowska, R. (2011). Edukacja informacyjna w polskiej szkole. Warszawa: Wydaw. SBP.

Próchnicka, M. (2007). Information literacy. Nowa sztuka wyzwolona XXI wieku. W: J. Dzieniakowska (red.). Ksiązka, biblioteka, informacja - między podziałami a wspólnota. Kielce: Wydaw. Akademii Świętokrzyskiej, 433-445.

Resmini, A.; Rosati, L. (2012). A Brief History of Information Architecture [online]. Journal of Information Architecture, vol. 3, no. 2, [11.09.2016],http://journalofia.org/volume3/issue2/03-resmini/ 
Robins, D. (2002). Information Architecture in Library and Information Science Curricula, Bulletin of the American Society for Information Science and Technology, 28 (2), 20-22.

Roman, W. K. (2012). Podstawy zarzadzania informacją, Toruń: Wydaw. Nauk. UMK.

Rosenfeld, L.; Morville, P. (2003). Architektura informacji w serwisach internetowych, Gliwice: Helion. Skórka, S. (2002). Architektura informacji. Nowy kierunek rozwoju informacji naukowej [online], Biuletyn EBIB, 11 (40), [11.09.2016], http://www.ebib.pl/2002/40/skorka.php

Skórka, S. (2008). Funkcje i zadania architekta informacji w społeczeństwie wiedzy. W: D. Pietruch-Reizes, W. Babik (red.). Wymiana informacji i rozwój profesjonalnych ustug informacyjnych w edukacji, nauce i kulturze na rzecz społeczeństwa opartego na wiedzy. Katowice: PTIN, 157-162.

Sosińska-Kalata, B. (1995). Podręcznik UKD dla bibliotekarzy i pracowników informacji, Warszawa: Wydaw. SBP.

Sosińska-Kalata, B. (2004). Czym jest dziś nauka o informacji (tytułem wstępu). W: B. Sosińska-Kalata, K. Materska, W. Gliński (red.). Spoteczeństwo informacyjne i jego technologie. Warszawa: Wydaw. SBP, 9-12.

Świgoń, M. (2006). Bariery informacyjne. Podstawy teoretyczne i próba badań w środowisku naukowym. Warszawa: Wydaw. SBP.

Tafiłowski, P. (2015). Exemplis discimus - księga jubileuszowa osiemdziesięciolecia Profesora Edwarda Potkowskiego, red. P. Tafiłowski. Lublin: Studenckie Koło Informacji Naukowej „Palimpsest”, Instytut Informacji Naukowej i Bibliotekoznawstwa UMCS.

\title{
Information Architecture as a Research Problem within the Frame of Information Science
}

\begin{abstract}
Purpose/Thesis: The purpose of this paper is to present a reflection on the relationship between Information Architecture and Information Science, both as scientific disciplines and the everyday practice of university education.

Approach/Methods: The considerations concerning the placement of Information Architecture within the framework of Information Science were started when the author was an employee of the Institute that planned to start a degree course called "Information Architecture". This was necessary since the plans to set up such a field of studies met with a lot of resistance from the faculty council. Results and conclusions: The reflection on the range of issues included in the scope of interest of Information Architecture as well as on the research issues of informatology and the curriculum within its frames indicates that Information Architecture fits into the range of interests of Information Science to a large extent.

Originality/Value: It seems justified to undertake this type of discussion and to provide an argumentative answer to the question "Why should informatologists teach Information Architecture?". The attempts to launch such a course in the framework of our discipline aroused controversy and objections of our colleagues employed in other institutes, fellow members of the faculty or university authorities. Also, the competences of researchers in Information Science in this field are questioned. This paper attempts to dispel all arising doubts. This type of reflection has not been presented so far.
\end{abstract}

Keywords

Information architecture. Education. Information Science. Informatology. 
Dr hab. PIOTR TAFIŁOWSKI, adiunkt w Katedrze Informatologii na Wydziale Dziennikarstwa, Informacji $i$ Bibliologii Uniwersytetu Warszawskiego. W pracy naukowej i dydaktycznej zajmuje się bibliologia historyczna, dziejami komunikacji spotecznej oraz zagadnieniami informatologii. Najważniejsze nowe publikacje: Media spotecznościowe jako źródto informacji bibliograficznej w naukach humanistycznych. Komunikat z badań, „Zagadnienia Informacji Naukowej. Studia Informacyjne” 54 (2016), nr 1 (107), s. 55-66; The Duels of Monarchs: the Issue of Ritual Communication from Antiquity to the Present Day, "Theatrum Historiae" 18 (2016); Geographical Horizons of the Poles in 16th Century from the Perspective of Social Communication [w:] Editionswissenschaftliches Kolloquium 2015 : Die Geschichte im Bild, herausgegeben von H. Flachenecker, K. Kopiński und J. Tandecki, Toruń 2016, 27-33; Rejestracja rękopiśmiennych i drukowanych poloników w zbiorach zagranicznych - problem wciaż otwarty, „Roczniki Biblioteczne” 58 (2014) [druk 2015], 87-100; Anti-Turkish Literature in 15th-16th Century Europe, „Tarih Incelemeleri Dergisi”, XXX/1 (2015), 231-280; Antyturecka korespondencja Macieja Korwina i Sykstusa IV : przyczynek do dziejów propagandy w stosunkach międzynarodowych w późnym średniowieczu, „Zeszyty Naukowe Uniwersytetu Jagiellońskiego. Prace Historyczne", 143 (2016), 1, 37-55.

Kontakt z autorem: p.tafilowski@gmail.com Katedra Informatologii Wydziat Dziennikarstwa, Informacji i Bibliologii Uniwersytet Warszawski Nowy Świat 69, p. 313 00-927 Warszawa 